\title{
Detection of the mutation may guide treatment of heart and muscle in Duchenne muscular dystrophy
}

This article was published in the following Dove Press journal:

International Medical Case Reports Journal

3 March 2016

Number of times this article has been viewed

Josef Finsterer'

Sinda Zarrouk-Mahjoub ${ }^{2}$

'Krankenanstalt Rudolfstiftung, Vienna, Austria; ${ }^{2}$ Genomics Platform, Pasteur Institute of Tunis, Tunis, Tunisia
Correspondence: Josef Finsterer Krankenanstalt Rudolfstiftung, Postfach 20, II 80 Vienna, Austria $\mathrm{Tel}+43$ । 7 II 6592085

Fax +43 | 478 I7। I

Email fifigs।@yahoo.de

\section{Dear editor}

We read with great interest the article, by Kono et al, about a 32-year-old male with Duchenne muscular dystrophy (DMD), who was admitted for dilated cardiomyopathy manifesting as heart failure, left bundle branch block, Mobitz-II block, bradycardia, and arterial hypotension. He profited from implantation of a cardiac resynchronization therapy-D system with a defibrillator and beta-blocker treatment. ${ }^{1}$ We have the following comments and concerns.

Diagnosing DMD only by muscle biopsy is insufficient. The diagnosis needs to be confirmed by genetic studies. ${ }^{2}$ Was the patient investigated for deletions, duplications, or point mutations in the $D M D$ gene? Which were the results of the Western blot for dystrophin? Was there complete absence of dystrophin or were there indications for a truncated protein, compatible with the diagnosis of Becker muscular dystrophy (BMD)? Since the patient was quite old for DMD, it has to be convincingly shown that BMD was definitively excluded. Diagnosing DMD on a molecular genetic level is important as genetic therapy in form of exon skipping is available for a certain type of mutations. ${ }^{3}$

It has been shown that patients with DMD profit from the administration of steroids, usually deflazacort. ${ }^{4}$ There are indications that steroids not only improve the performance of the skeletal muscle but also improve cardiac functions. ${ }^{5}$ Furthermore, steroids reduce the myocardial fibrosis burden in these patients as has been shown by cardiac magnetic resonance imaging (MRI) ${ }^{6}$ Did the presented patient receive steroids in addition to heart failure therapy? Did he profit from steroids with regard to cardiac and muscle function? Which side effects did he develop from steroids?

Dilated cardiomyopathy in DMD is characterized by replacement of the myocardium with connective tissue. ${ }^{6}$ Myocardial fibrosis in DMD can be best documented by application of cardiac MRI and administration of gadolinium to assess the amount of late gadolinium enhancement (LGE). ${ }^{6}$ Did the patient undergo cardiac MRI and was gadolinium administered to assess the amount and location of myocardial fibrosis? Assessment of LGE in DMD is important since the amount of LGE strongly correlates with left ventricular systolic dysfunction. ${ }^{6}$

Approximately two-thirds of the DMD patients inherit the mutation from their mothers. DMD carriers may manifest clinically or biochemically. Was the mother of the described patient investigated for her carrier status? Did she manifest clinically or were there other indications for being a DMD carrier? Did she undergo electrocardiography 
(ECG) recording or echocardiographic investigations? Was a cardiac MRI carried out and did it show LGE as has been previously reported. $^{7}$

Overall, this interesting case presentation would profit from more extensive genetic and cardiologic investigations to assess the degree of myocardial fibrosis and from evaluation of the genetic background in this particular patient and his relatives.

\section{Disclosure}

The authors report no conflicts of interest in this work.

\section{References}

1. Kono T, Ogimoto A, Nishimura K, Yorozuya T, Okura T, Higaki J. Cardiac resynchronization therapy in a young patient with Duchenne muscular dystrophy. Int Med Case Rep J. 2015;8:173-175.

2. Swaminathan B, Shubha GN, Shubha D, et al. Duchenne muscular dystrophy: a clinical, histopathological and genetic study at a neurology tertiary care center in Southern India. Neurol India. 2009;57:734-748.
3. Adkin CF, Meloni PL, Fletcher S, et al. Multiple exon skipping strategies to by-pass dystrophin mutations. Neuromuscul Disord. 2012;22: 297-305.

4. Biggar WD, Politano L, Harris VA, et al. Deflazacort in Duchenne muscular dystrophy: a comparison of two different protocols. Neuromuscul Disord. 2004;14:476-482.

5. Mavrogeni S, Papavasiliou A, Douskou M, Kolovou G, Papadopoulou E, Cokkinos DV. Effect of deflazacort on cardiac and sternocleidomastoid muscles in Duchenne muscular dystrophy: a magnetic resonance imaging study. Eur J Paediatr Neurol. 2009;13:34-40.

6. Tandon A, Villa CR, Hor KN, et al. Myocardial fibrosis burden predicts left ventricular ejection fraction and is associated with age and steroid treatment duration in Duchenne muscular dystrophy. J Am Heart Assoc. 2015;26;4(4).

7. Florian A, Rösch S, Bietenbeck M, et al. Cardiac involvement in female Duchenne and Becker muscular dystrophy carriers in comparison to their first-degree male relatives: a comparative cardiovascular magnetic resonance study. Eur Heart J Cardiovasc Imaging. 2015;25.

Dove Medical Press encourages responsible, free and frank academic debate. The content of the International Medical Case Reports Journal 'letters to the editor' section does not necessarily represent the views of Dove Medical Press, its officers, agents, employees, related entities or the International Medical Case Reports Journal editors. While all reasonable steps have been taken to confirm the content of each letter, Dove Medical Press accepts no liability in respect of the content of any letter, nor is it responsible for the content and accuracy of any letter to the editor.

International Medical Case Reports Journal

\section{Dovepress}

\section{Publish your work in this journal}

The International Medical Case Reports Journal is an international, peer-reviewed open-access journal publishing original case reports from all medical specialties. Previously unpublished medical posters are also accepted relating to any area of clinical or preclinical science. Submissions should not normally exceed 2,000 words or
4 published pages including figures, diagrams and references. The manuscript management system is completely online and includes a very quick and fair peer-review system, which is all easy to use. Visit http://www.dovepress.com/testimonials.php to read real quotes from published authors.

Submit your manuscript here: http://www.dovepress.com/international-medical-case-reports-journal-journal 